\title{
Uncovering Buried Volcanoes: New Data for Probabilistic Volcanic Hazard Assessment at Yucca Mountain
}

\author{
Frank V. Perry \\ (fperry@lanl.gov, 505 667-1033) \\ Allen H. Cogbill (ahc@lanl.gov) \\ Richard E. Kelley (rekelley@lanl.gov) \\ Earth and Environmental Sciences Division \\ EES-9, MS D452 \\ Los Alamos National Laboratory \\ Los Alamos, NM 87545
}

Basaltic volcanism poses a potential hazard to the proposed Yucca Mountain nuclear waste repository because multiple episodes of basaltic volcanism have occurred in the Yucca Mountain region (YMR) in the past $11 \mathrm{Ma}$. Intervals between eruptive episodes average about $1 \mathrm{Ma}$. Three episodes have occurred in the Quaternary at approximately $1.1 \mathrm{Ma}$ (5 volcanoes), $350 \mathrm{ka}$ (2 volcanoes), and $80 \mathrm{ka} \mathrm{(1} \mathrm{volcano).} \mathrm{Because} \mathrm{Yucca}$ Mountain lies within the Basin and Range Province, a significant portion of the preQuaternary volcanic history of the YMR may be buried in alluvial-filled basins. An exceptionally high-resolution aeromagnetic survey and subsequent drilling program sponsored by the U.S. Department of Energy (DOE) began in 2004 and is gathering data that will enhance understanding of the temporal and spatial patterns of Pliocene and Miocene volcanism in the region (Figure 1). DOE has convened a ten-member expert panel of earth scientists that will use the information gathered to update probabilistic volcanic hazard estimates originally obtained by expert elicitation in 1996.

Yucca Mountain is a series of north-trending ridges of eastward-tilted fault blocks that are bounded by north to northeast-trending normal faults. Topographic basins filled with up to $500 \mathrm{~m}$ of alluvium surround it to the east, south and west. In the past several decades, nearly 50 holes have been drilled in these basins, mainly for Yucca Mountain Project Site Characterization and the Nye County Early Warning Drilling Program. Several of these drill holes have penetrated relatively deeply buried (300-400 m) Miocene basalt; a Pliocene basalt dated at $3.8 \mathrm{Ma}$ was encountered at a relatively shallow depth $(100 \mathrm{~m})$ in the northern Amargosa Desert (Anomaly B in Figure 1). The current drilling program is the first to specifically target and characterize buried basalt. Based on the new aeromagnetic survey and previous air and ground magnetic surveys (Connor et al. 2000; O'Leary et al. 2002), at least eight drill holes are planned with the goal of sampling each geographic subpopulation of magnetic anomalies in the region (Figure 1). This will result in a more complete characterization of the location, age, volume and composition of buried basaltic features for the purpose of updating the volcanic hazard assessment.

Smith and Keenan (2005) suggested that volcanic hazard estimates might be 1-2 orders of magnitude higher than estimated by the DOE expert elicitation in 1996, based on (1) a proposed relationship between recurrence rates in the YMR and the Reveille-Lunar Crater volcanic field to the north, and (2) the implication that a number of so-farundiscovered buried volcanoes would have a significant impact on hazard estimates. This 
article presents the new aeromagnetic data and an interpretation of the data that suggests magnetic anomalies nearest the proposed repository site represent buried Miocene basalt that will likely have only a minor impact on the volcanic hazard.

\section{Expert Elicitation}

The 1996 expert panel estimated the mean annual probability of a volcanic disruption of the repository is $1.5 \times 10^{-8}$ volcanic disruptions (vent or dike intersections) per year, equating to a probability of about 1 in 7000 in the next 10,000 years (Bechtel SAIC, 2004). The uncertainty distribution derived from the experts' assessments spanned about three orders of magnitude, from $10^{-7}$ to $10^{-10}$ volcanic disruptions per year. The main contributions to the uncertainty were from uncertainty in estimates of the recurrence rate for volcanic events and alternative interpretations of the appropriate models for the spatial distribution of future volcanism. The number, age, and location of buried volcanoes will directly affect both of these parameters. In 1996, the expert panel primarily considered the post-Miocene (the past $5 \mathrm{Ma}$ ) volcanic history as important in assessing the volcanic hazard. Recurrence intervals within this period range from a few hundred thousand years to 1 or 2 million years, resulting in recurrence rates on the order of $10^{-5}$ to $10^{-6}$ volcanic episodes per year. These low rates largely account for the low hazard value of about $10^{-8}$ volcanic disruptions per year. With one exception (at $3 \mathrm{Ma}, 30$ $\mathrm{km}$ northeast of Yucca Mountain), basaltic volcanoes younger than $5 \mathrm{Ma}$ occur to the south, west and northwest of the repository site. This spatial distribution of volcanism was a significant factor in the 1996 hazard assessment. The discovery of buried Pliocene basalt immediately to the east of Yucca Mountain in Jackass Flats would significantly change the current understanding of the spatial distribution of post-5 Ma basalt in the YMR and potentially increase the volcanic hazard. Conversely, because several known Miocene basalt units outcrop in Jackass Flats, discovery of additional buried Miocene basalt would likely have little impact on the hazard estimate.

\section{Aeromagnetic Survey and Drilling}

The aeromagnetic survey completed in 2004 provides much higher spatial resolution than previous surveys, while still covering a relatively large area of $865 \mathrm{~km}^{2}$, including Yucca Mountain and adjacent basins to the east, west and south (Figure 1). A total of 16,000 km of east-west survey lines were flown by helicopter at a flight-line spacing of $60 \mathrm{~m}$ and an instrument height that was typically $40-45 \mathrm{~m}$ over flat terrain. Principal instrumentation was a total-field cesium-vapor magnetometer. The resolution of the survey is nearly equivalent to ground magnetic surveys previously conducted locally in the region (Connor et al. 2000), but coverage over the survey area is uniform, permitting detection of volcanic and structural features that were not well-resolved by previous aeromagnetic surveys.

A regional aeromagnetic survey conducted in 1999 (O'Leary et al., 2002) revealed a complex pattern of aeromagnetic anomalies to the east of Yucca Mountain in Jackass Flats. The new survey provides much better resolution of faults in this area and, combined with surface exposures of Miocene basalt and existing drill hole results, leads 
to the conclusion that only Miocene basalt is present in Jackass Flats. This conclusion, discussed below, will be tested by additional drilling and sample dating.

The most prominent magnetic feature in Jackass Flats is a broad linear positive anomaly (Anomaly $U$ ) that parallels the eastern edge of the survey from central Jackass Flats to the northern edge of Anomaly B at the southeastern edge of the survey (Figure 1).

Anomaly $U$ is interpreted to represent buried Miocene basalt for two reasons. First, it includes a 9.6 Ma, fault-bounded basalt outcrop near its north end. Faults evident in the aeromagnetic data adjacent to this outcrop both laterally displace buried basalt to the northeast and down-drop buried basalt to the west (Figure 1). Farther to the south, the buried basalt is progressively down-faulted to the southwest as indicated by increasingly attenuated anomaly signals bounded by northwest-trending faults. Second, drill hole 23P near the south end of the anomaly intersected a 10-meter-thick basalt at a depth of $400 \mathrm{~m}$ that was dated at 9.5 Ma (Michael Kunk, written comm.). A series of deep ( $>350 \mathrm{~m}$ ) drill holes immediately to the west of Anomaly U intersected alluvium and Miocene tuff, but did not encounter basalt, further limiting the possibility that buried Pliocene basalt is present in Jackass Flats.

Two of the drill holes in the current program have been completed to date. A sequence of four thin basalt flows (1-4 m thick) was intersected at Anomaly Q in Crater Flat between a depth of 141 and $163 \mathrm{~m}$ (bottom of hole). Landslide deposits of Paleozoic strata emplaced during the Miocene uplift of Bare Mountain were encountered immediately above the basalt flows. These stratigraphic relationships are identical to those encountered in drill hole VH-2, five $\mathrm{km}$ south of Anomaly Q, and in outcrop at the southern margin of Crater Flat (Figure 1). The basalts in drill hole VH-2 and in outcrop are both dated at about $11.3 \mathrm{Ma}$, leading to the conclusion that the basalt flows encountered at Anomaly Q are also 11.3 Ma. By correlation, Anomalies R and 4, adjacent to Anomaly $Q$ in northern Crater Flat, are thus also interpreted to represent buried Miocene basalt.

At Anomaly A in Crater Flat, basalt was encountered beneath alluvium at a depth of 148 $\mathrm{m}$. Lack of flow features and evidence of internal differentiation suggest this basalt may be a sill or a conduit. Stratigraphic relationships at this site do not allow an interpretation of the age; sample dating will provide that information.

\section{Implications}

Although confirmation awaits the completion of drilling and sample dating, interpretation of the new aeromagnetic data and drilling results to date suggest that magnetic anomalies adjacent to Yucca Mountain in Crater Flat and Jackass Flats are due to buried Miocene volcanic features. Sensitivity analyses can give insight into how much probability estimates might be impacted if a number of Pliocene volcanoes were buried in Crater Flat and Jackass Flats. These analyses, based on models used in the 1996 expert elicitation, considered two primary scenarios (Bechtel SAIC, 2004). The first assumed that 22 anomalies (none of which were located in Jackass Flats) identified from previous air and ground magnetic surveys represented buried Pliocene volcanoes. This scenario resulted in 
an increase in the hazard estimate of $40 \%$, a relatively small change well within the orders-of-magnitude uncertainty of the 1996 estimate. A second scenario postulated a minimum of 5 and 9 additional buried Pliocene volcanoes in Crater Flat and Jackass Flats, respectively, in addition to those assumed from previous magnetic surveys, bringing the total minimum number of assumed buried Pliocene volcanoes to 36 . In this scenario, the mean hazard estimate increased to $8.0 \times 10^{-8}$, a factor of 5 increase over the 1996 estimate. Based on the much smaller number of Pliocene volcanoes suggested by interpretation of the aeromagnetic data and drilling results thus far, this value likely represents an upper bound to hazard values and suggests that the impact on hazard estimates due to buried Pliocene volcanoes will be less than an order of magnitude.

Alternative models that allow a significant increase in future recurrence rates could increase the hazard estimate. Smith and Keenan (2005) proposed such a model, suggesting that the Lunar Crater volcanic field (LCVF), $150 \mathrm{~km}$ to the NNE of the YMR, is linked to processes in the YMR through a common and anomalously hot asthenospheric mantle source. The key implication is that recurrence rates in the YMR could increase to rates typical of the LCVF in the future. This hypothesis is inconsistent with the Quaternary volcanic history of the two volcanic fields, which for the past million years have differed significantly in terms of recurrence rate and volume of basalt erupted. Compared to the eight Quaternary scoria cones in the YMR, there are approximately 80 Quaternary scoria cones in the LCVF with a total eruption volume that is 1-2 orders of magnitude greater than the eruption volume of the YMR in the Quaternary. The major differences in eruptive volume and recurrence rates, as well as major differences in $\mathrm{Nd}$ and $\mathrm{Sr}$ isotopic composition, are consistent with models of hotter asthenospheric mantle and colder lithospheric mantle sources, respectively, for the LCVF and YMR (Farmer et al. 1989; Lum et al. 1989). As a whole, the data indicate that the Lunar Crater and YMR volcanic fields have independent eruptive histories, and mantle sources with different magma production potentials, and should not be linked for purposes of assessing volcanic hazard at Yucca Mountain.

The charge to the current expert panel is to evaluate all the data they consider pertinent to hazard assessment that have become available since the time of the original expert elicitation in 1996, and to incorporate these data into hazard models. The aeromagnetic and drilling data, although key, are not the only new data that the experts will consider. An updated assessment of the volcanic hazard at Yucca Mountain, which will incorporate data from the completed drilling program and the expert's interpretation of the aeromagnetic data, awaits completion of the expert elicitation.

\section{Acknowledgements}

The work reported here was funded by the U.S. Department of Energy's Yucca Mountain Project, via Bechtel-SAIC LLC. 


\section{References}

Bechtel SAIC Company (2004), Characterize framework for igneous activity at Yucca Mountain, Nevada: Las Vegas, Nevada, Bechtel SAIC Company, ANL-MGR-GS000001 REV 02.

Connor, C. B., J. A. Stamatakos, D. A. Ferrill, B.E. Hill, G. I. Ofoegbu, F. M. Conway, B. Sagar, and J. Trapp (2000), geologic factors controlling patterns of small-volume basaltic volcanism: application to a volcanic hazards assessment at Yucca Mountain, Nevada." J. Geophys. Res., 105, 417-432.

Farmer, G. L., F. V. Perry, S. Semken, B. Crowe, D. Curtis, and D. J. DePaolo (1989), Isotopic evidence on the structure and origin of subcontinental lithospheric mantle in southern Nevada, J. Geophys. Res., 94, 7885-7898.

Lum, C. L., W. P. Leeman, K. A. Foland, J. A. Kargel, and J. G. Fitton (1989), Isotopic variations in continental basaltic lavas as indicators of mantle heterogeneity: examples from the western U.S. cordillera, J. Geophys. Res., 94, 7871-7884.

O’Leary, D.W., E. A. Mankinen, R. J. Blakely, V. E. Langenheim, and D. A. Ponce (2002), Aeromagnetic expression of buried basaltic volcanoes near Yucca Mountain; Nevada, U.S. Geol. Surv. Open File Rep., 02-020.

Smith, E.I, and D.L. Keenan (2005), Yucca Mountain Could Face Greater Volcanic Threat, EOS, 86, 317, 321 . 
Figure 1. Residual magnetic field (measured total field minus the International Geomagnetic Reference Field) for Yucca Mountain and surrounding basins from the 2004 helicopter-borne survey. WWF (Windy Wash Fault) and PCF (Paintbrush Canyon Fault) in the central part of the survey define the general boundaries between uplifted Miocene tuffs of the Yucca Mountain range block and the Crater Flat and Jackass Flats basins. The Bare Mountain Fault defines the western edge of the Crater Flat Basin. Alphanumeric labels indicate anomalies suspected of representing buried basalt based on previous air and ground magnetic surveys. Solid lines enclose outcrops of Quaternary $(\mathrm{Qb})$, Pliocene $(\mathrm{Pb})$ and Miocene $(\mathrm{Mb})$ basalt. Dashed lines enclose areas of inferred buried basalt associated with outcrops of Pliocene and Miocene lava flows. Red-filled circles indicate existing drill holes, white-filled circles indicate drill holes planned for the current drilling program. The bar and ball symbols on faults denote the downthrown side. 


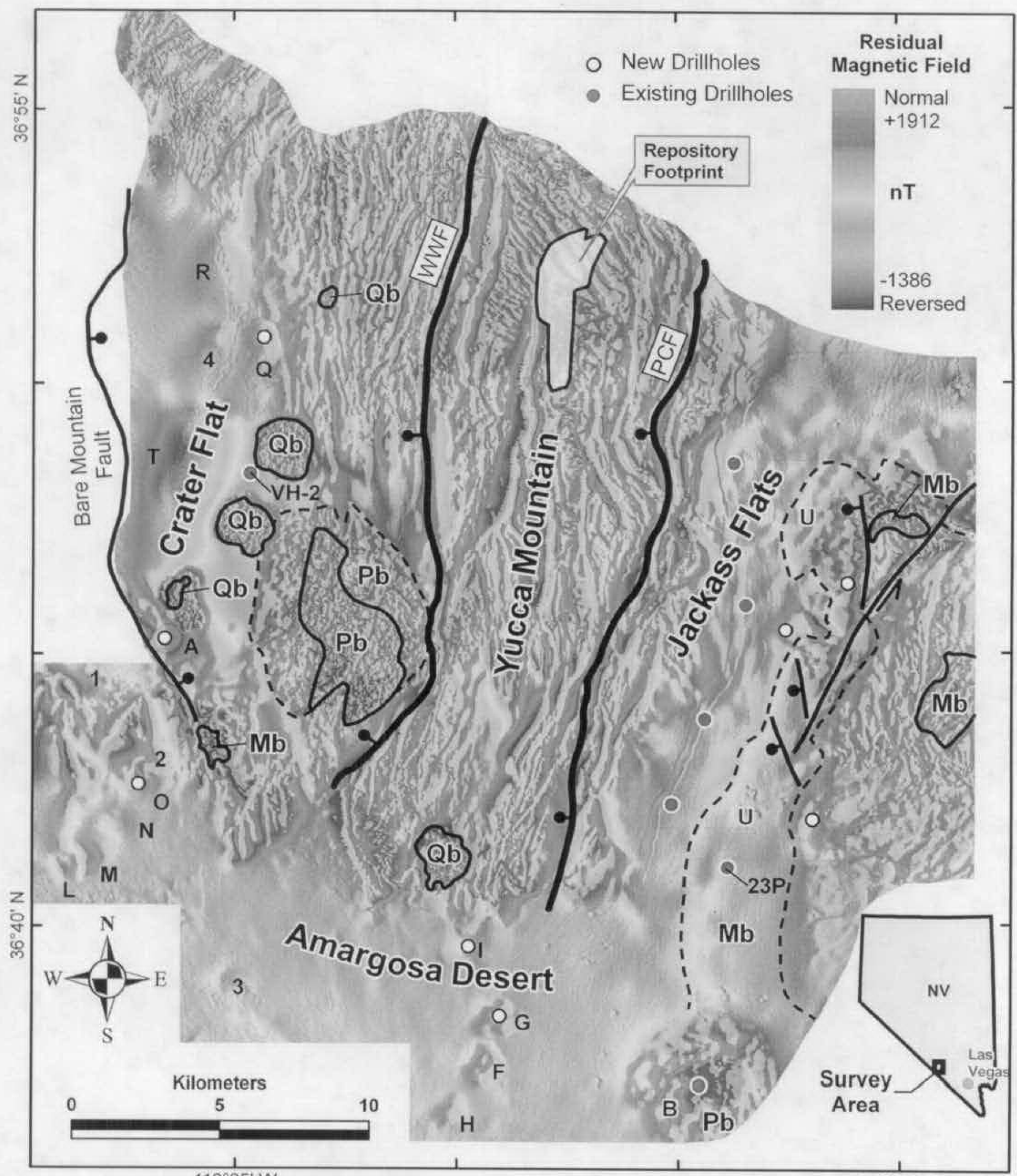

